Borja Herce

\title{
Past-future asymmetries in time adverbials and adpositions: A crosslinguistic and diachronic perspective
}

DOI 10.1515/lingty-2017-0003

Received December 7, 2015; revised September 28, 2016

Abstract: Expressions like English ago have been claimed to be among the most likely candidates for postposition crosslinguistically, and the reason for this has been conjectured to be diachronic. A few previous contributions notwithstanding, however, we still lack a typologically wider-ranging account of such temporal adpositions and adverbials and of how they develop. These are the main goals of the present article. Relying on a sample of 100 languages, it has been found that: (i) the structure instantiated in English by ago is far from universal and is geographically unevenly distributed; (ii) these expressions are indeed predominantly postposed, which does not hold for their mirror images for the future; and (iii) evidence from etymology, patterns of polysemy, and documented semantic extensions suggests that this asymmetry is the result of past and future markers having different diachronic sources.

Keywords: adposition, adverbial, grammaticalization, polysemy, syntax, temporal deixis, word order

\section{Introduction}

This article aims to sketch a crosslinguistic picture of synchronic word order in expressions for deictic localization in the past (e.g., English ago, French il y a, German vor, Russian nazad, etc.) and in the future (e.g., English in, French dans, German in, Russian čerez, etc.) as well as of their diachronic sources. In Section 2 the topic is introduced and the scope of the present analysis is circumscribed. Section 3 reviews earlier contributions to the topic and points out some of their limitations. Etymological, morphological, and syntactic differences frequently found between past and future deictic expressions are observed in Section 4. Section 5 presents the language sample for the

Borja Herce, Letren Fakultatea, Euskal Herriko Unibertsitatea, Unibertsitateko Ibilbidea 5, 01006 Vitoria-Gasteiz, Spain, E-mail: borjaherce@gmail.com 
quantitative crosslinguistic analysis of word order in relevant constructions and Section 6 explores the presence and absence of the target construction in the sample languages as well as their areal patterns and social concomitants. In addition, the most frequent syntactic and semantic alternatives to these constructions are surveyed. Sections 7 and 8 present the word order patterns of the expressions for past and future deictic location respectively, introduce a distinction between monosemous and polysemous markers, and explore whether they conform to the dominant head-complement order in the respective languages. Patterns of polysemy of the markers with multiple time-related uses, the semantics of the time relations involved, the etymological profile of the expressions, and their different word order patterns are argued to provide evidence for two different grammaticalization paths giving rise to these expressions and responsible for the noted asymmetry. In the concluding Section 9 the findings are summarized, some tentative explanations are suggested, and additional research targets are proposed to complement the contributions of the present study.

\section{Domain of study}

Time is one of the most salient aspects of human experience and cognition. The coding of time in language is, therefore, a central component of grammar and has received considerable attention from the linguistic community. Most of those efforts have been centered on the verbal domain, i.e., on tense or aspect, while others, such as time adverbials, have received much less coverage. This is unfortunate because some languages are altogether bereft of inflectional morphology for tense (e.g., Mandarin Chinese) or aspect (e.g., German). In addition, tense and/or aspect play only a secondary role compared to adverbials in the coding of time relations, especially when these are highly precise.

Time adverbials are generally described (e.g., van der Auwera \& Ó Baoill (eds.) 1998) as syntactically optional elements which function mainly as modifiers of non-nominal constituents. They comprise extremely varied expressions in both their morphosyntactic composition and semantics. These expressions may be morphologically simple (English now, often ...), or they may be morphologically (English currently, later ...) or syntactically complex. These latter are very diverse: they may be adverbial phrases (e.g., two days before), adpositional phrases (e.g., in a week), bare noun phrases (e.g., summer 1944), or clauses (e.g., when you came). Regarding their semantics, time adverbials can describe 
duration (e.g., for an hour), frequency (e.g., every year), contrast (e.g., already), or position.

Of this last type are expressions like English two years ago or Spanish hace dos años. Ago or hace are part of a phrase which also includes a time NP which specifies the time elapsed from some event in the past up to the present. The phrase as a whole is thus used to indicate the location of the event time (E) at a given distance (D) before the present (S) which is taken as the reference time $(\mathrm{R})$ :

(1) John came [two years ago]

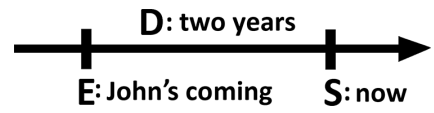

Words like English ago or Spanish hace have a transparent lexical origin, in the verbs go and hacer 'to make' respectively, but their synchronic categorial status is more controversial. Indeed, these expressions tend to be remarkably idiosyncratic within their languages. Ago, for instance, is arguably the only postposition of English (Culicover 1999: 71-74; Kurzon 2008), and its Italian equivalent $f a$ shares this same uniqueness in its own language. These expressions contrast prominently with their mirror images for the future, English in or Italian tra, which only involve a secondary use of spatial prepositions and can therefore be included more easily into one of the conventional word classes.

These are the subclasses of temporal adverbials which are analysed here: they are syntactically complex, optional, and non-clausal expressions which provide the location in time of the main event or situation relative to the origo or utterance time. They do so by specifying, in the form of a time NP, the distance separating the present from the time of the event. This may be either in the past (e.g., English ago, French il y a, Spanish hace, Basque duela, German vor, Russian nazad, etc.) or in the future (e.g., English in, French dans, Spanish dentro de, Basque barru, German in, Russian čerez, etc.). In order to delimit the object of study, both semantic and formal considerations have been included: i.e., the time distance to the utterance time must be specified by an NP. This is the same approach followed, for example, by Haspelmath (1997: 6) since, as he mentions, a purely notional, semantic definition of the object of study would be impossible. Some terminological shortcut is required to refer to these specific constructions throughout the rest of this article. To avoid a longer term I 
will refer to these expressions in general as TIME DISTANCERS; ${ }^{1}$ thus, expressions such as English ago or Spanish hace will be called past distancers and English in or Spanish dentro de future distancers independently of their categorial status or syntactic role. The phrases these expressions introduce will be referred to as time distance phrases or, when more specificity is required, as past distance phrases or future distance phrases. ${ }^{2}$

\section{Previous contributions}

Although time distancers have not been an exceedingly popular research topic, they have not passed totally unnoticed either. For example, they constitute a subset of the NP-based time adverbials studied by Haspelmath (1997). The synchronically peculiar properties of many past distancers have recently attracted scholarly attention as well (Kurzon 2008). Problems posed by past distancers in specific languages, both diachronic (Franco 2012) and synchronic (Culicover 1999: 71-74; Rigau 2001; Móia 2011; Fábregas 2016), have also been addressed. Haspelmath (1997) and Franco (2013) noticed the frequent formal identity of time distancers and other time expressions and of time distancers and certain spatial expressions. This will be explored later. Some asymmetries between past distancers and future distancers have also been commented on before. When considering specifically some of the sources of time distancers, Haspelmath (1997: 86) already noticed a "surprising lack of symmetry" between those for the past and those for the future. For past distancers he mentions verbs like pass or exist and adverbs like back. For future distancers, common sources involve spatial inclusion (within) or movement (across) or the adverb yet. However, little additional attention has been given to the diachronic, as well as synchronic, differences that are frequently found between past and future deictic markers and between the phrases of which they are part.

The fact that these expressions and adverbials in general are an understudied linguistic domain, despite their important role, can probably be

1 My thanks are due to Martin Haspelmath for suggesting this term.

2 The relevant markers or expressions have been labeled in different ways in the literature. For instance, they have been called "temporal deictic expressions" by Kurzon (2008) and "temporal distance markers" by Haspelmath (1997), and their semantic contribution has been labeled “deictic scalar localization” by Bourdin (2011). 
explained in part by their sheer complexity. As was mentioned above, these are very diverse expressions in terms of their composition, their word categorization, or their syntactic position and nature.

Indeed, the properties of past distancers often make them exceedingly difficult to research from a typological perspective. Many are hard to categorize. As mentioned by Kurzon (2008), ago, for example, has been variously analysed as an adverb, as a postposition, and as a preposition. Culicover (1999: 71-74) showed, however, that its properties cannot be fully captured by traditional allor-nothing Aristotelian categorization. Unless we are ready to prioritize arbitrarily some grammatical properties over others we are simply forced to acknowledge the idiosyncrasy of this particular expression and some of its equivalents in other languages. Probably as a result, a comprehensive crosslinguistic picture of past distancers has so far eluded us. What is more, the synchronic properties of these expressions, let alone their diachronic developments, are at times so peculiar that when a comparative approach has been pursued, misinterpretations have not been uncommon.

Kurzon (2008), for example, explored the past distancers across 26 languages. However, his analysis of many of the expressions is open to dispute. Finnish sitten, for example, is claimed to be a postposition "which governs the partitive case [...] when the noun in the temporal NP is in the plural [...] while in cases when the singular is referred to, the nominative is used" (Kurzon 2008: 219):

(2) Finnish
a. kaksi päivää sitten
two day.PART.SG ago
'two days ago' (Kurzon 2008: 219)
b. vuosi sitten
year.NOM.SG ago
'a year ago' (Kurzon 2008: 219)

This would indeed be something unique in the language, since most postpositions govern the partitive case - but, logically, they do so in both singular and plural (Karlsson 1991: 241). What seems to be happening in these examples is that it is the numeral which is governing the partitive case in (2a) whereas in (2b) there is no numeral to do so. Note that after numerals other than 'one' the partitive singular is used in Finnish (Karlsson 1991: 110).

On the same page, Kurzon also classifies the Turkish past distancer önce as a postposition, rather than as an adverb preceded by an extent phrase, which is Haspelmath's (1997: 82) analysis of the expression. The problem in this case 
seems to be that the location-in-the-past function (marked in English by ago) is being confused with the anterior (indicated in English by before). Both time relations are in Turkish coded with the same expression önce, but with a different syntactic structure. Contrary to Kurzon's claim (Kurzon 2008: 219), bir yil-dan önce [one year-ABL before] does not mean 'one year ago' but rather 'before one year' and should therefore have remained outside the study since it is not deictic. Instead, bir yil önce [one year.NOM ago] could have been included, since it makes the appropriate semantic contribution.

In addition, Kurzon seemed determined to classify every single past distancer as either adpositional or adverbial. To do so, “inconvenient" properties of the expressions in question had sometimes to be disregarded. For example, he argues (Kurzon 2008: 216) that such past distancers as Spanish hace and French il y $a$ are synchronically prepositional on the basis of their being invariable in form. This, however, is not the situation in those two languages, since nonpresent forms of the expressions are indeed possible:

(3) Spanish

Le había visto hacía una semana

him had seen make.IPF a week

'I had seen him a week earlier.'

In a similar vein, after mentioning (Kurzon 2008: 223) that the past distancer in Bislama (English-based creole, Oceania) might be "even verbal”, he proceeds to classify the expression as adverbial because, apparently, he had only two taxa in his taxonomy of past distancers.

Trying to straitjacket every single word in a language into a rigid grammatical category may not always be the most fruitful approach. Trying to do so with such idiosyncratic expressions as past distancers - and besides in languages with which the researcher has little acquaintance - is likely to be unsuccessful. For this reason, the following typological research has focused chiefly on the word order of the time distancer with respect to the accompanying time NP. No claims are made here about the grammatical category of specific time distancers or the specifier or complement role of the time NP. By confining the analysis to this readily accessible and uncontroversial feature and relating it to the dominant word-order patterns in each language, it will hopefully be possible to steer clear of errors like those mentioned above, while providing relevant information about the nature of the expressions crosslinguistically. 


\section{Preliminary observations}

In Section 2 some differences between past and future distancers were introduced which seemed to constitute an interesting past-future asymmetry. An initial look at these expressions reveals that this asymmetry appears to involve syntactic differences in both word order and morphological complexity such as the ones exemplified in (4). Past distancers are on the left side while future distancers are on the right.

(4) a. English (and translation for (4b-e)) I came [two years $\underline{\text { ago] }} \quad$ I will come [in two years]

b. Basque [Duela bi urte] etorri nintzen [Bi urte barru] etorriko naiz

c. Italian Sono venuto [due anni fa] Verrò [tra due anni]

d. Russian Ja prišel [dva goda nazad] Ja pridu $[\underline{\text { čerez }}$ dva goda]

e. French Je suis venu [il y a deux ans] Je vais venir [ $\underline{\text { dans }}$ deux ans]

The asymmetry also seems to involve etymological differences. For example, while many past distancers (on the left side) are synchronically based upon a lexical, open class item, most usually a verb, future distancers (on the right side) are most commonly based upon grammatical elements:
a. English: a-go < prefix-'go'
in < 'in'
b. Basque: du-ela < 'have.3SG-COMP'
barru < 'inside'
c. Italian: $f a<$ 'make.3SG'
tra $<$ 'behind'
d. Russian: na-zad < 'to-back'
čerez < 'across'
e. French: il y $a<$ 'it there have.3SG' dans < 'inside'

All in all, future distancers appear initially to be more strongly grammaticalized than their past-time equivalents and to be more unremarkable within their respective languages. Past distancers, by contrast, often appear to be badly aligned with the dominant word order of their respective languages and they sometimes exhibit quite idiosyncratic properties, ${ }^{3}$ which is probably the reason why they have attracted more attention than future distancers.

3 Contrary to the examples in (4), many languages use ordinary spatial adpositions as past distancers (e.g., German, vor 'before'). 
It has to be stressed at this point that the asymmetries that have been presented for time distancers in (4) are not paralleled by other very similar time-related but non-deictic expressions. Thus, for example, no such asymmetry is found between expressions whose reference time is not the present or speech time but some other point on the time axis instead, see, e.g., two years before and two years later or, with the same meanings, Spanish dos años antes and dos años después. These are all adverbs specified by measure phrases and heading adverbial phrases in a little-surprising syntactic position. This seems to suggest that it is the opposition of past and future meaning which is relevant (if not responsible) for the differences. It will be interesting to observe whether the expressions which have time-deictic as well as non-deictic uses ${ }^{4}$ tend to pattern like deictics or like non-deictics and whether the preliminary observations presented in this section hold crosslinguistically.

\section{The sample}

With the aim of answering this question and to prove whether or not the asymmetry between past and future distancers is a crosslinguistically valid generalization and to quantify it, a sample of 100 genetically and geographically diverse languages has been chosen; see Table 1 . The availability of relevant information was a decisive criterion in selecting the sample. ${ }^{5}$ As a consequence, the sample is somewhat biased towards European and Indo-European languages. However, this is arguably not a fatal flaw when studying time distancers. One of the most remarkable facts about these expressions is precisely that even closely related languages tend to use different, non-cognate expressions - which suggests expressive strategies that are relatively unstable diachronically and tend to be renewed frequently. ${ }^{6}$ Therefore, trying to ascertain which are the diachronic sources of these expressions will have to be one of the main goals of the present research.

\footnotetext{
4 As discussed by Haspelmath (1997: 80-90), many languages lack a distinction between deictic and sequential markers; that is, they have a single expression for a past distancer like ago and a marker of anteriority like before.

5 This lack of randomness disqualifies this as a sample in the strict sense; call it a "convenience sample", then.

6 See in Appendix B the time distancers of Romance, Slavic, Celtic, Turkic, Semitic, or Finnic languages.
} 
Table 1: Sample languages and their genetic affiliation (languages in italics are those lacking the structure under study; further information to be provided in Section 6).

\begin{tabular}{|c|c|}
\hline Genus & Sample languages \\
\hline Indo-European & $\begin{array}{l}\text { Dutch, English, German, Swedish, French, Italian, Romanian, Spanish, } \\
\text { Bulgarian, Polish, Russian, Serbian/Croatian, Hindi, Pashto, Persian, } \\
\text { Punjabi, Breton, Irish, Welsh, Latvian, Lithuanian, Albanian, Armenian, } \\
\text { Greek }\end{array}$ \\
\hline Afro-Asiatic & Arabic, Hausa, Hebrew, Maltese, Mehri, Oromo, Mani \\
\hline Niger-Congo & Igbo, Swahili, Thimbukushu, Yoruba, Babungo, Supyire \\
\hline Austronesian & Indonesian, Maori, Tagalog, Muna, Tuvaluan \\
\hline Sino-Tibetan & Mandarin Chinese, Taiwanese, Tibetan, Lepcha, Thangmi \\
\hline Dravidian & Kannada, Malayalam, Tamil, Telugu \\
\hline Uralic & Estonian, Finnish, Hungarian, Udmurt \\
\hline Nakh-Daghestanian & Chechen, Hunzib, Lezgian \\
\hline Pama-Nyungan & Dyirbal, Warlpiri, Bilinarra \\
\hline Tungusic & Evenki, Nanai, Udihe \\
\hline Arawan & Jarawara, Tariana \\
\hline Central Solomons & Lavukaleve, Savosavo \\
\hline Creoles & Haitian, Saramaccan \\
\hline Na-Dené & Slave, Tsilhqút'ín \\
\hline Tai-Kadai & Lao, Thai \\
\hline Turkic & Azeri, Turkish \\
\hline Uto-Aztecan & Hopi, Ute \\
\hline \multirow{2}{*}{\multicolumn{2}{|c|}{$\begin{array}{l}\text { Genera represented by one sample language: } \\
\text { Abkhaz-Adyge (Abkhaz), Timor-Alor-Pantar (Abui), Nyulnyulan (Bardi), Pano-Tacanan } \\
\text { (Caviñena), Kartvelian (Georgian), Carib (Hixkaryana), Japonic (Japanese), Eskimo-Aleut } \\
\text { (Kalaallisut), Tangkic (Kayardild), Koreanic (Korean), Nilotic (Lango), Oto-Manguean (Mixtec), } \\
\text { Mongolic (Mongolian), Algonquian (Nishnaabemwin), Quechuan (Quechua), Austroasiatic } \\
\text { (Semelai), Totonacan (Tepehua), Mayan (Tzutuji), Chapacuran (Wari'), Yukaghir (Yukaghir) }\end{array}$}} \\
\hline & \\
\hline Isolates & Basque, Nivkh \\
\hline
\end{tabular}

\section{Presence and absence of time distancers and their corresponding constructions}

The structure we are concerned with here - a syntactically complex optional phrase containing a time NP specifying the time separating some event from the present - is ubiquitous in the most widespread European and Asian languages and we might be tempted to take its presence for granted. However, the precise measurement, record, and segmentation of time is a 
cultural feature which is more prominent in some cultures and societies than in others. Thus, it must be taken into account that not all languages need to match the degree of precision with which an event can be located in time in most European languages. In addition, the same semantics provided by time distancers may be conveyed by constructions different from the one that concerns us here. The result, therefore, is that some languages simply do not have the linguistic structures which are being analysed here. ${ }^{7}$ These languages are shown in Table 1 in italics.

Probably one of the most extreme cases in this respect, for speakers of European languages at least, is represented by Wari' (Chapacuran, Brazil). According to Everett \& Kern (1997: 139), time adjunction as a whole is absent from the language. Time information can apparently only be provided by the use of verbal modifiers which combine with the verb root to produce a compound. Also remarkable to Western ears is the situation in Jarawara (Arawan, Brazil), where, according to Dixon \& Vogel (2004: 409), not only is the construction analysed here lacking, but even a specific word for 'when?' is also missing. To inquire about time one must resort to circumlocutions:

\section{(6) Jarawara}

Hika bahi itara

where sun sit

'What time is it? [lit., Where does the sun sit?]' (Dixon \& Vogel 2004: 409)

Somewhat less extreme seems to be the situation in Dyirbal (Pama Nyungan Australia), where lexicalized, unanalysable expressions have been described (by Dixon 1972: 115) as the only adverbial resource to locate an event in the past with a certain degree of precision. We find, among others, buluru 'very many years ago', bandagay 'many years ago', gubila 'some time ago'. Evans (1995: 229) describes something very similar for Kayardild (Tangric Australia), where we find yuujbanda 'in the old days', kurdiwirdi 'some time ago', or dilaya 'a few days ago'. These monomorphemic expressions do not lend themselves to

7 The presence or absence of time distancers in most of the sample languages has been determined by their presence or absence in descriptive grammars. This approach, of course, is not without problems, since "all grammars leak". To minimize this risk only languages with in-depth grammatical descriptions have been included in the sample. In addition, the absence of time distancers from a particular language has only been posited where some sort of negative evidence was found in the grammar - such as semantically equivalent constructions like the ones analysed in this section or/and explicit reports of absence in the grammar. 
the kind of analysis I am pursuing here and are therefore outside the scope of the present study.

Something slightly different is what we find in Lepcha (Tibeto-Burman, Bhutan). Plaisier (2006: 93) lists the following time adverbials:

$\begin{array}{lll}\text { (7) Pi-tshóng 'two days } & \begin{array}{l}\text { Pyo-chám 'three days } \\ \text { ago' }\end{array} & \begin{array}{l}\text { Pyo-chót 'four days } \\ \text { ago' }\end{array} \\ \text { ka-tshóng 'in two days' } & \text { ká-chám 'in three days' ká-chót 'in four days' }\end{array}$

Unlike the Australian time adverbs, the expressions seem to be morphologically complex. The strategy, however, appears not to be available for other time periods (e.g., 'six days ago'). In addition, the morphemes tshóng, chám, and chót are confined to this construction and are not the usual terms for 'two', 'three', and 'four'. Interesting though this construction might be, these time adverbials have therefore also been excluded from further consideration.

A different strategy is represented by Babungo (Niger-Congo, Cameroon). When expressing precisely the location in time of some event, this language exclusively uses biclausal structures:

a. Đwá tâa jwì fấ váshī vábj̀ shổ

he FUT come [when days two pass.IPFV]

'He'll come in two days [lit., he will come when two days have passed].' (Schaub 1985: 169, cited after Haspelmath 1997: 55)

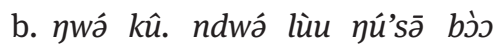

he die now be years two

'He died two years ago [lit., He died. It's now two years].'

(Schaub 1985: 169, cited after Haspelmath 1997: 55)

In some languages, therefore, the phrase which expresses the time distance separating an event from the present is always a clause in itself and is, thus, outside the scope of the present analysis. These constructions have been excluded because clausal elements often have very different properties from non-clausal ones and may not be comparable despite their identical semantics. Sententials, for instance, tend to have a freer syntax in languages where word order is not rigid, which would have been problematic for the analysis of languages to which the linguist has only limited access (in some cases a single sentence) and no knowledge of his own whatsoever. The Spanish examples below illustrate the different constituent order flexibility of sentential (9a, 10a, 11a) and non-sentential elements (9b, 10b, 11b): 
(9)
a. Hace diez dias que te vi
it.makes ten days that you.ACC saw.1SG
'It has been ten days since I saw you.'
b. Hace diez dias te vi
ago ten days you.ACC saw.1SG
'I saw you ten days ago.'

(10)
a. Hace $q$ que te $\quad$ vi $\frac{\text { diez dias }}{\text { it.makes that you.ACC saw.1SG ten days }}$ 'It has been ten days since I saw you.'
b. ${ }^{*}$ Hace te $v i$
$\underline{\text { diez dias }}$ ago you.ACC saw.1SG ten days
[Intended meaning:] 'I saw you ten days ago.'
(11) a. Diez dias hace que te vi
ten days it.makes that you.ACC saw.1SG
'It has been ten days since I saw you.'
b. ${ }^{*}$ Diez dias hace te vi
ten days ago you.ACC saw.1SG
[Intended meaning:] 'I saw you ten days ago.'

We should wonder at this point whether the presence or absence of time distancers in a given language is predictable from or correlated to some other factor. Some areas appear to be specially prone to lacking this construction, as can be seen in Map 1. Apart from the aforementioned Dyirbal and Kayardild, other sample languages from Oceania like Warlpiri, Bilinarra, Lavukaleve, and Tuvaluan lack it as well. Languages in Amazonia also appear to be similar in this respect. Apart from Wari' and Jarawara, Caviñena, Tariana, or Hixkaryana appear to lack time distancers. Languages in the rest of America and in Africa often seem to lack them as well. By contrast, not a single European language has been found to lack this construction. This is also uncommon in Asian languages according to my sample.

Even if the distribution of the sample languages is not geographically balanced, the areal pattern of these time constructions is unmistakeable enough not to be attributable to chance. This geographic pattern, however, is most probably caused by something else in turn, since geographical location of speech communities per se (i.e., latitude and longitude) is unlikely to influence the syntactic structures of a language. If we look at the languages in the sample which lack time distancers we easily find some traits in common. Without 


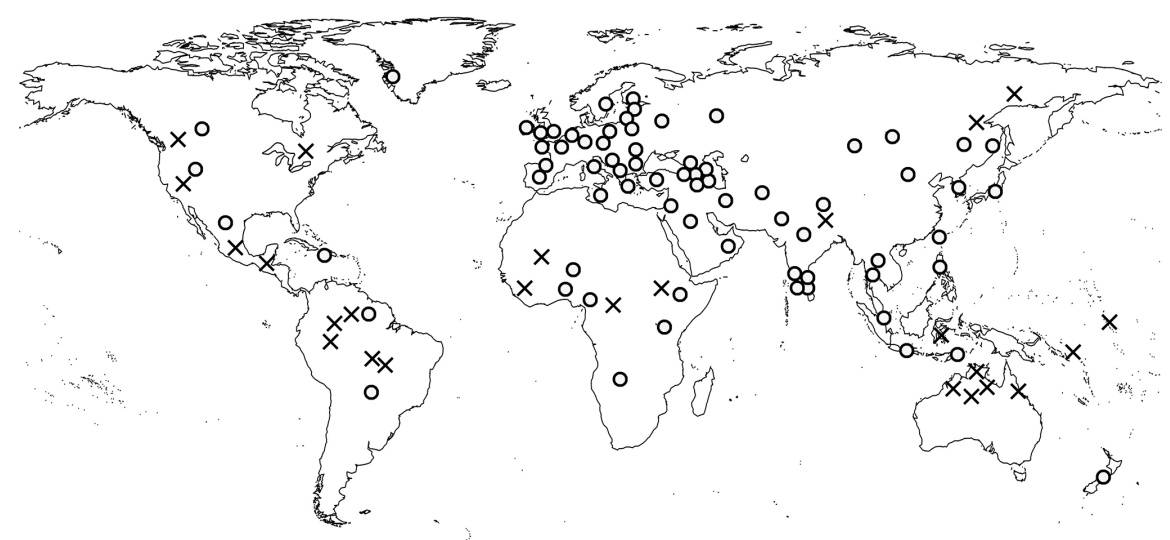

Map 1: Geographic location of the languages in the sample and presence (circles) vs. absence (crosses) of time distancers.

exception they are languages spoken in predominantly rural or hunter-gatherer communities and with a modest number of speakers; see Figure 1. Possibly, there is a functional evolutionary explanation for this trend. Language is a social instrument which has to serve the needs of the community where it is spoken. Languages spoken in mountainous areas, for instance, sometimes have the vertical axis integrated into their morphology for spatial deixis (Schapper 2014), while this is extremely rare in languages spoken in flat terrains. A higher frequency of use of that spatial dimension in these mountainous areas may over time lead to the grammaticalization of those spatial relations. In flat areas, the vertical axis is used less frequently and the relevant morphology either does not develop or is lost because it is less useful there.

Similarly, it is not difficult to imagine that whereas most speakers of Hixkaryana, Babungo, or Savosavo rarely need to express something as precise as 'in five weeks' or 'twelve years ago', the situation will be different among speakers of Dutch, Basque, or Korean. In urban, bureaucratic, polychronic societies, speakers will need to be able to express location in time with absolute precision. In addition, if these meanings arise in discourse with sufficient frequency, there might be a strong pressure for languages spoken in these contexts to have these structures available. ${ }^{8}$ This is of course just an impressionistic

8 The idea that languages evolve to meet the communicative needs of their speakers is not new (e.g., Deutscher 2000; Bybee 2010; Dixon 2010: 15-22) and is indeed what one expects if one accepts usage-based explanations of language change. 


\section{Presence of time distancers}

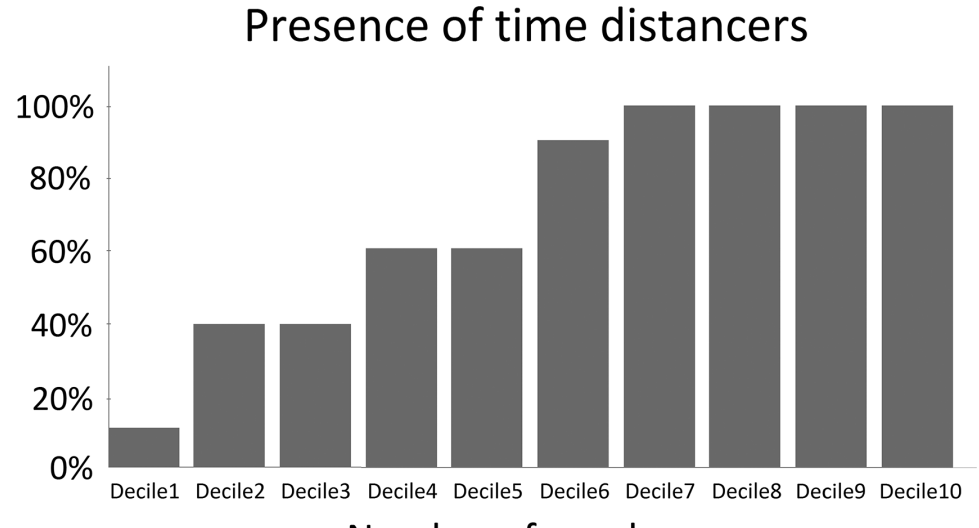

- Number of speakers +

Figure 1: Proportion of languages having time distance phrases ordered by number of speakers.

attempt to explain patterns emerging from the present study. Investigating the frequency of appearance of such time relations in oral registers in different languages would help support or dismiss these speculations.

\section{Past distancers and their phrases crosslinguistically}

Past distancers occur across languages in any possible word order with respect to their accompanying time NP. Thus, they may precede it (12), follow it (13), or, as the third logical possibility, a discontinuous expression may precede and follow it at the same time (14). I present below examples for each of the attested word orders with the past distance phrase between brackets and the past distancer in bold:

(12) a. Basque

[Du-ela hamar urte] jaio zen

has-COMP ten year born was.3SG

'He was born ten years ago.'

b. Arabic

Kunit hunak ['abil juma']

was.1SG there ago week

'I was there a week ago.' (Kurzon 2008: 217) 
(13) a. Punjabi

[Do saal páílãã asĩ Multaan gae

two year ago we Multaan went

'Two years ago we went to Multaan.' (Bhatia 1993: 206, cited in Haspelmath 1997: 82)

b. Russian

Ja priexal sjuda [tri nedeli nazad]

I came.M to.here three weeks ago

'I came here three weeks ago.'

(14) a. Swedish

Jag var $i$ Stockholm [för tre år sedan]

I was in Stockholm ago three years ago

'I was in Stockholm three years ago.'

b. Amharic

[Kə and saat bəfit] izzih nabbərə

ago one hour ago here was.3SG.M

'He was here an hour ago.' (Kurzon 2008: 217)

In Table 2, I classify the languages in my sample according to whether their past distancer is preposed or postposed to the time $\mathrm{NP}^{9}$ and according to whether the language in question is predominantly prepositional or post positional. ${ }^{10}$ This is meant to detect (i) correlations between the ordering of

Table 2: Correlation between order of adpositions and of past distancers (PD).

\begin{tabular}{lrr}
\hline & Prepositional languages & Postpositional languages \\
\hline NP PD & 21 & 31 \\
PD NP & 16 & 1 \\
\hline
\end{tabular}

9 The two cases which, like Swedish, display a past distancer which is both pre- and postposed have been counted as 0.5 for each of the two positions. For some languages (e.g., English ago vs. back, Italian fa vs. addietro) more than one expression is found with the same semantics. In these cases the most frequent variant was chosen for analysis.

10 As (almost) any typologist knows, the order of an adposition and its complement is strongly correlated with that of the verb and its object. Almost all of the prepositional languages in the sample therefore display the basic word order VO and almost all of the postpositional languages are OV. The few cases where the two parameters do not co-occur as expected have been indicated in Appendix A. 
past distancers and of adpositions and (ii) crosslinguistic preferences for the placing of past distancers.

There are two things which emerge here. On the one hand, it can be seen that, crosslinguistically, the past distancer has a strong general tendency to be postposed to the time NP. This had been suggested impressionistically by Plank (2011: 457): "of all adpositions, ago is universally among the most likely candidates (perhaps the most likely) for postposing even in languages where prepositions hugely predominate". This seems to be confirmed here since 52 out of 69 expressions (75.4\%) are postposed in the present sample. Despite this overall preference for postposition, there seems to be a very clear correlation between the order of a past distancer and the dominant order of adpositions in the language in question. Thus, prepositional languages show preposed and postposed past distancers with a comparable frequency whereas postpositional languages have a very strong preference for a postposed past distancer. From the 32 postpositional languages in the sample for which I have relevant data, only a single one, Basque, has a preposed past distancer. The chisquared test (even with Yates's correction; see, e.g., Brown 2004) shows that the differences displayed in Table 2 are statistically highly significant $(p=0.0003)$.

This single exception of a postpositional language showing a preposed past distancer could well be a result of language contact since Basque has for a long time been a neighbour of both Spanish and French, languages where preposed past distancers are used. This hypothesis of contact influence is supported by the fact that, up to the seventeenth century, the same expression that in presentday Basque appears preposed (see (12a)) was indeed postposed:

(15) Basque (1617-1623)

Beha egotu naiz ea zer erraiten zuten iendek nik looking be AUX.1SG Q what say AUX.3PL people.ERG I.ERG [zenbait urthute duela] eskiribatu nuen giristinoaren Dotrinaz some years ago write have.PST.1SG Christian doctrine 'I have been looking at what people say about the Christian doctrine I wrote some years ago.' (Euskal Klasikoen Corpusa, http://www.ehu.eus/ehg/kc/)

Until approximately that time the Spanish past distancer was predominantly postposed as well, so language contact would not have exerted a pressure towards preposing. Only when later on, especially during the eighteenth century, preposing of the past distancer became mainstream in Spanish through the replacement of haber by hacer, did the Basque language come under 
pressure to switch the order of its past distancer phrase to fit the one found in the neighbouring languages:

(16) Basque (1740)

Orai [duela laur egun] othoitzean nindagoen ... now ago four day praying AUX.PST.1SG

'I was praying four days ago now ...' (Euskal Klasikoen Corpusa, http:// www.ehu.eus/ehg/kc/)

It is always difficult to prove beyond doubt that a given change was the result of language contact, but the evidence presented quite strongly suggests that it may have been at least an important factor here and that language contact should not be dismissed when analysing the word order of these expressions.

One factor which has been left out of the equation until now is that past distancers may be monosemous (i.e., may have the location of an event at a certain point in the past as their only time-related semantic function) or may be polysemous. In fact, as argued by Haspelmath (1997: 80-90) and as shown more graphically by Franco (2013: 53), many past distancers are also put to use in the expression of other temporal relations. Very frequently they can also be used for "retrospective" and "anterior" uses:

(17) German

a. Vor vierzig Jahren gab es hier eine wunderbare Landschaft ago forty years existed it here a wonderful landscape 'Forty years ago there was a wonderful landscape here.'

b. Mein Vater wurde zehn Jahre vor Beginn des Zweiten my father was ten years before beginning of.the Second Weltkriegs geboren

World.War born

'My father was born ten years before the beginning of the Second World War.'

c. Vor dem Essen war ich nicht hungrig

before the meal was I not hungry

'I wasn't hungry before the meal.'

(18) Lezgian

a. dümdüz 250 jis idalaj wilik

exactly 250 years this before

‘exactly 250 years ago’ (Haspelmath 1997: 82) 
b. däwedilaj wilik

war before

'before the war' (Haspelmath 1997: 82)

Examples (17a) and (18a) have the semantics that have been defined as the object of study in this article, which Haspelmath (1997) called "distance-past". The semantic contribution is different in example (17b), since it does not make reference to the utterance time but rather the time distance is counted backwards from another time reference. It is usually called "distanceretrospective". Examples (17c) and (18b) are more different still from distance-past in that they neither refer to utterance time nor do they specify the time distance mediating between reference time and event time. Because of this, they are usually referred to simply as "anterior”. See Figure 2 for a schematic illustration of these time relations.

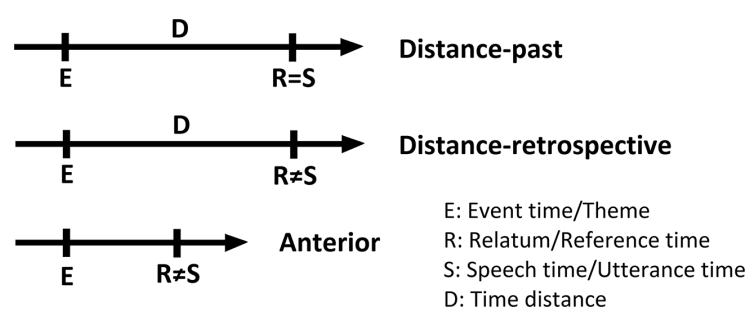

Figure 2: Semantic composition of distance-past, distance-retrospective, and anterior time relations.

Crosslinguistically, therefore, past distancers can be specialized exclusively for their use in the distance-past function or may have other temporal uses (such as, for example, the previous ones). To see if the properties of the expressions are significantly different depending on whether they are dedicated to distance-past or not, I have analysed the correlation between the word order of past distancers (PD) and that of adpositions. The results are shown in Table 3.

The count shows that the word order of the two types of past distancers shows indeed remarkable differences. Those which are not confined in their use to the distance-past function pattern very much like adpositions. Only 5.7\% (2 out of 35) of the languages in the sample for which I have the relevant data 
Table 3: Word order of monosemous and polysemous past distancers (PD).

\begin{tabular}{lcccr}
\hline & $\begin{array}{c}\text { Monosemous past distancers } \\
\text { Prepositional } \\
\text { languages }\end{array}$ & $\begin{array}{l}\text { Postpositional } \\
\text { languages }\end{array}$ & $\begin{array}{l}\text { Prepositional } \\
\text { languages }\end{array}$ & $\begin{array}{l}\text { Polysemous past distancers } \\
\text { Postpositional } \\
\text { languages }\end{array}$ \\
\hline NP PD & 9 & 1 & 2 & 21 \\
PD NP & 4 & 1 & 12 & 0 \\
\hline
\end{tabular}

deviate from the predominant word order found there. All the word order "extravagance" and "maladaptiveness" observed in past distancers as a whole, therefore, is found in those used exclusively for the expression of that time relation. Yates's chi-squared test shows that, in prepositional languages, the difference found in the word order of monosemous and polysemous past distancers is statistically significant $(p=0.012)$.

From the observed patterns I hypothesize two things. First, from the "messy" properties and ill-aligned word order of monosemous past distancers vis-à-vis their non-dedicated counterparts one may infer that distance-past is a time relation in which erstwhile free, discursive expressions first become a part of grammar. This would explain the characteristics of past distancers that were presented in Section 3 such as their often synchronically recoverable lexical (frequently verbal) origin as well as the word order properties found here. Given the most frequent diachronic sources of adpositions and adpositional phrases, ${ }^{11}$ the word order patterns that have been presented for past distancers are not unexpected.

Secondly, Franco (2013) shows that the possible semantics of polysemous past distancers are subject to a constraint whereby a given expression cannot be used for the distance-past and anterior functions without being used to express distance-retrospective as well; examples are in Table 4. The bottom part of

11 As Plank (2011: 460) mentions, "the commonest sources of adpositions-in-adpositionalphrases are verbs-in-verb-phrases (primarily transitive, typically in some non-finite construction), head-nouns-in-attributive-phrases (with body parts and other relational nouns as heads) and (local and temporal) adverbs gaining an obligatory complement”. When grammaticalizing from verbs, which is quite frequent among past distancers as has been shown, this predicts that in SVO languages both a preposition (out of VO) and a postposition (out of SV) are possible outcomes whereas in SOV languages the only possible outcome would be a postposition. This agrees with the general correlations found here. Note that prepositional languages are frequently SVO whereas postpositional languages are in most cases SOV. 
Table 4: Time relations of polysemous past distancers (adapted from Franco 2013: 53). Unlike in Franco (2013), no claims are made in this article about the syntactic analysis of these expressions.

\begin{tabular}{llll}
\hline Language & Anterior & Distance-retrospective & Distance-past \\
\hline English & before & before & ago \\
German & vor & vor & vor \\
Maltese & qabel & qabel & ilu \\
Serbian/Croatian & prije & prije & prije \\
Spanish & antes & antes & hace \\
Turkish & önce & önce & önce \\
Old Florentine & prima & addietro & addietro \\
Modern Italian & prima & prima & addietro (also fa) \\
\hline
\end{tabular}

Table 4 shows how either anterior or distance-past team up with distanceretrospective in different diachronic stages of Italian.

As can be seen graphically in Figure 2, the semantics of distanceretrospective is indeed intermediate between the other two. ${ }^{12}$ It is thus not surprising that, when diachronic semantic extensions occur in these expressions, a morph will necessarily need to adopt the intermediate meaning (distance-retrospective) before reaching the final one (distance-past). The constraint observed synchronically by Franco (2013) is thus the expected outcome of "normal" diachronic semantic extensions. It is at this point when our data come into play once again. The fact that the "extravagant" properties of past distancers are limited to monosemous ones is an indication that semantic extensions among these three functions proceed from the anterior function towards distance-past via distance-retrospective ${ }^{13}$ and rarely (or never) in the opposite direction. Current etymological knowledge of polysemous past distancers like vor, prije, or önce as well as attested diachronic developments like Franco's Italian example of Table 4 also seem to support the same diachronic path (see Figure 3).

12 It could be argued, on empirical grounds, that the difference between deictic (distance-past) and non-deictic time relations (distance-retrospective and anterior) is the most fundamental one. As can be seen in Table 4, a different morphosyntactic coding of distance-past and distance-retrospectivity is more frequent than a different coding of distance-retrospectivity and anteriority.

13 This involves, as can be seen in Figure 3, successive steps of interpretative enrichment, which constitutes a development "entirely expected from a Gricean point of view" (Haspelmath 1997: 84) and is arguably the result of the natural tendency of the speaker to always assume more than is being said. 


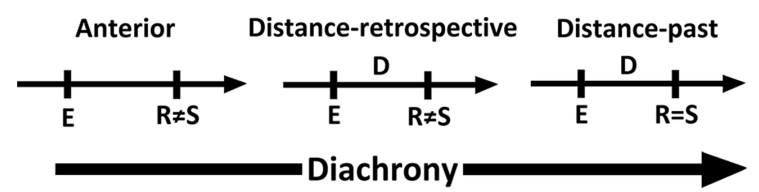

Figure 3: Main direction for semantic change.

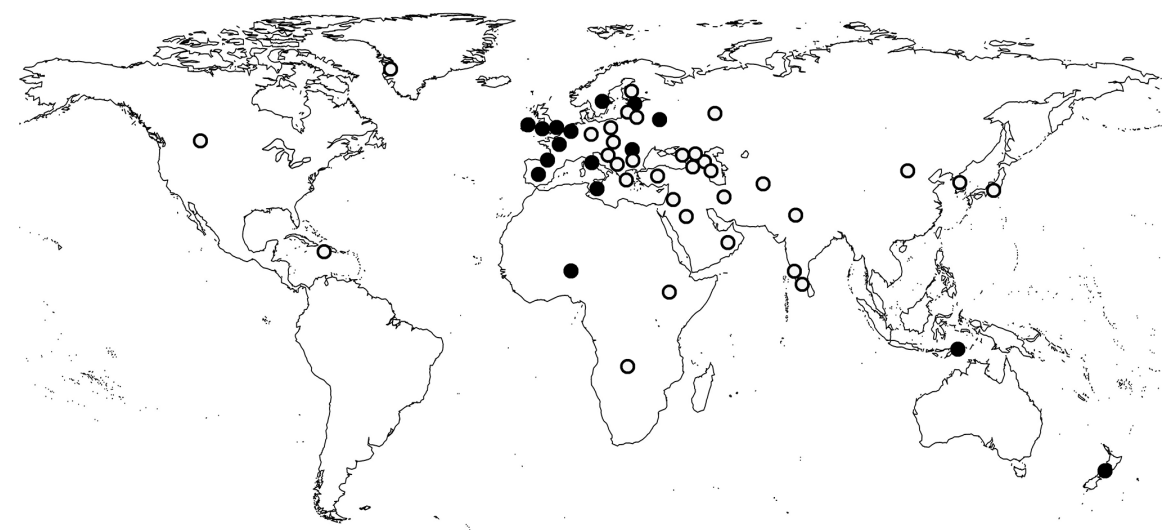

Map 2: Geographic distribution of monosemous (black circles) and polysemous (white circles) past distancers.

Other interesting patterns can also be extracted from the results of my typological survey of past distancers, though always with the necessary precautions because of the modest numbers in the present sample. It looks remarkable, for example, that semantically dedicated past distancers are almost completely restricted to Europe and are specially frequent in Western Europe. In Map 2, I present the global distribution of monosemous past distancers. As can be seen, only 3 out of 16 languages with a monosemous past distancer in this sample are outside Europe. Thus, this might be another one of the crosslinguistically uncommon features of so-called "Standard Average European", and it might then be hypothesized, in line with my preliminary explanation at the end of Section 6, that a greater Western-culture preoccupation with time measurement is probably the reason behind it. If the different time relations emerged in speech more frequently in European society and languages than in other parts of the world, this could have been a motivation for a greater clarity in this respect - i.e., for the use of different morphs and structures for the different 
time relations. A similar and highly compatible possibility was mentioned by Haspelmath (1997: 55), who proposed that the greater frequency of these constructions in Europe may have triggered the grammaticalization of some biclausal structures (like those from Babungo illustrated in Section 6) into monoclausal ones, thus increasing the frequency of dedicated past distancers in this region. This diachronic development seems to be responsible for the emergence of these expressions in English, French, Italian, Spanish, Basque, or Maltese, for example.

\section{Future distancers and their phrases crosslinguistically}

Future distancers, like past distancers, may occur preposed and postposed to the time NP. Unlike past distancers, however, no future distancers have been found to occur circumposed to their time NP. Conversely, the distance-future semantic function has been found expressed by a particular grammatical case ending on the time NP, something which did not occur with distancepast. It has to be stressed again that the numbers are probably not big enough to confidently generalize about consistent distinctions between future and past distancers; however, they seem to be in line with the overall higher grammaticalization of future vis-à-vis past distancers. Here are a few examples of pre- and postposed as well as of grammatical case-marked future distancers:

a. Spanish

Una expedición viajará a Marte [dentro de quince años] an expedition travel.FUT.3SG to Mars inside of fifteen years 'An expedition will travel to Mars in fifteen years.'

b. Modern Greek

Tha jiriz-o [se tris óres]

FUT return-1SG in three hours

'I will return in three hours.' (Haspelmath 1997: 90)

c. Basque

[Bi urte barru] amaitu-ko ditu ikasketak

two year inside end-FUT AUX.3SG studies

'He/she will finish his/her studies in two years.' 
d. Turkish

[İki saat sonra] don-eceğ-im

two hour after return-FUT-1SG

'I will be back in two hours.' (Kornfilt 1997: 262, cited after Franco 2013: 7)

e. Malayalam

naan [ranto manikkuur-il] matanni ettaam

I two hour-LOC return arrive

'I shall get back in two hours.' (Asher \& Kumari 1997: 242)

f. Georgian

[Or saat-ši $]$ davbrundebi

three hour-LOC I.will.return

'I will return in three hours.' (Haspelmath 1997: 90)

Another sign of the overall higher degree of grammaticalization of future distancers is the fact that, unlike with past distancers, the time NP alone, without any overt marking, can sometimes function as a future distancer phrase. This is what Kruspe (2004: 244) describes for Semelai (Mon-Khmer, Malaysia): hmpe? ?are? loc [three day ago] 'three days ago' and tmpsh $P$ are? [seven day] 'in seven days'. Kung (2007: 505) reports the same phenomenon for Huehuetla Tepehua (Totonacan, Mexico): miix-kiis-chich [CL:days-five-ago] 'five days ago' and miix-kiis [CL:days-five] 'in five days'.

In Table 5, as was done in the previous section with past distancers, I classify the languages in the sample according to the position of their future distancers with respect to the time NP and according to whether the language in question is predominantly prepositional or postpositional. And the question will again be whether some correlation exists between the ordering of future distancers and adpositions and whether there is some crosslinguistic preference for their placement.

Table 5: Word order of future distancers (FD).

\begin{tabular}{lrr}
\hline & Prepositional languages & Postpositional languages \\
\hline NP FD & 2 & 28 \\
FD NP & 31 & 1 \\
\hline
\end{tabular}

As can be seen in Table 5, future distancers, unlike their mirror images for the past, are very "well-behaved" and pattern almost perfectly like adpositions. One of the two exceptions, a postposed marker in prepositional Persian, cannot be 
considered totally disharmonic either because, as a prepositional but SOV language, Persian exhibits mixed word order patterns. The other, Indonesian lagi, is grammaticalized from the adverb 'still' (Haspelmath 1997: 165), so its word order, even if synchronically out of line in the language, is diachronically understandable.

As with past distancers, a distinction can also be drawn between those future distancers having distance-future as their only time-related meaning and those polysemous morphs used with other meanings as well. The case of Turkish sonra is an example of a polysemous marker:

(20) Turkish

a. İki saat sonra don-eceğ-im

two hour after return-FUT-1SG

'I will be back in two hours.' (Kornfilt 1997: 262)

b. Sall-dan sonra bura-da ol-acağ-ım

Tuesday-ABL after here-LOC be-FUT-1SG

'I will be here after Tuesday.' (Kornfilt 1997: 263)

Since future distancers in general pattern almost perfectly like adpositions, no asymmetry can be expected this time between monosemous and polysemous expressions, and this is confirmed in Table 6.

Table 6: Word order of monosemous and polysemous future distancers (FD).

\begin{tabular}{lllllr}
\hline & \multicolumn{2}{c}{ Monosemous future distancers } & & \multicolumn{2}{c}{ Polysemous future distancers } \\
\cline { 2 - 3 } \cline { 5 - 6 } & $\begin{array}{l}\text { Prepositional } \\
\text { languages }\end{array}$ & $\begin{array}{l}\text { Postpositional } \\
\text { languages }\end{array}$ & & $\begin{array}{l}\text { Prepositional } \\
\text { languages }\end{array}$ & $\begin{array}{l}\text { Postpositional } \\
\text { languages }\end{array}$ \\
\hline NP FD & 0 & 2 & & 0 & 14 \\
FD NP & 10 & 0 & & 14 & 0 \\
\hline
\end{tabular}

This is an indication that, unlike distance-past, distance-future is usually not a locus for primary grammaticalization, i.e., for the change in the status of some element from lexical to grammatical. The patterns of polysemy seen in Section 7, however, also hold for future distancers and thus formal identity of distancefuture and posterior like in (20) can only be found if the semantically intermediate function "distance prospective" is also expressed with the same marker; see Table 7 for representative examples.

Regarding the diachronic semantic extensions which were hypothesized for past distancers in the previous section, therefore, there is in principle no 
Table 7: Time relations of polysemous future distancers (adapted from Franco 2013: 52).

\begin{tabular}{llll}
\hline Language & Posterior & Distance-prospective & Distance-future \\
\hline Albanian & pas & pas & pas \\
Haitian & apré & apré & nan \\
Hungarian & ultán & múlva & múlva \\
Japanese & go ni & go ni & go ni \\
Maltese & wara & wara & fi \\
Serbian/Croatian & poslije & poslije & do \\
\hline
\end{tabular}

reason to believe that they should proceed differently here. Thus, the posterior is probably a frequent, but by no means the only diachronic source of future distancers crosslinguistically. Given the unremarkable properties of even monosemous future distancers, distance-future may not be a frequent locus for primary grammaticalization, but it might be for so-called secondary grammaticalization. As witnessed by the spatial inessive semantics of many expressions (e.g., Spanish dentro de, French dans, Basque barru, ...), the use of such a spatial metaphor and the subsequent borrowing of the corresponding grammatical strategy from the domain of space may be quite frequent for expressing the distance-future function.

The monosemous preference of these inessive-based markers attracted the attention of Haspelmath (1997: 100): “'[w]ithin' markers never express both distance-future and distance-prospective, they are always purely deictic. It is not clear to me why this should be so". I believe that Haspelmath's observation that these markers are always dedicated to distance-future may constitute just an accidental gap in his data. On the one hand, we may be suspicious of the pattern on theoretical grounds alone: while the verbs often giving rise to past distancers already incorporate a deictic meaning, ${ }^{14}$ a 'within'-like expression in principle does not have deixis as an inherent part of its semantics. On the other hand and more importantly, it can be seen in the historical record that 'within' type future distancers which nowadays are restricted to distancefuture (e.g., Spanish dentro de) had earlier not only the 'within' meaning (21a) expected by Haspelmath, but also a prospective (21b) meaning independent of utterance time:

14 A present tense morphology in many cases anchors them to utterance time and disqualifies them for their use in any of the time relations presented here other than distance-past. 
(21) Eighteenth-century Spanish

a. Está vacante una Prebenda la cual segun los estatutos is vacant a position the which according.to the rules del mismo Colegio, se debe proveer dentro de cincuenta of.the itself college REFL must fill within of fifty dias desde el de la vacante days from the.one of the vacant.position 'There is a vacant position which according to the rules of the college itself must be filled within fifty days.' (CORDE (Corpus diacrónico del español), http://corpus.rae.es/cordenet.html, accessed August 2015)

b. Dixo-les que se vistiessen; y dentro de poco said.3SG-them that REFL get.dressed.3PL and inside of little tiempo bolvieron

time came.back.3PL

'He told them to get dressed and a little later they came back.' (CORDE, accessed August 2015)

The fact that prospective uses of dentro de extended over several centuries suggests that it can be a stable feature and that, in principle, there is nothing barring 'within' markers from non-deictic uses. Corpus evidence also confirms that the prospective use of dentro de clearly preceded its modern distance-future use. This semantic change from distance-prospective to distance-future in Spanish provides additional evidence for the diachronic trends proposed here.

Despite the big difference in the word order of monosemous markers for past and for future, what we do find is a similar proportion of dedicated future and past distancers (30\% and 31.4\% respectively). ${ }^{15}$ Monosemous future distancers, in addition, have a geographic distribution very close to that of monosemous past distancers. As shown in Map 3, monosemous future distancers are indeed completely restricted to European languages in the present sample, a pattern already identified by Haspelmath (1997: 100). This constitutes further evidence that our initial explanatory hypothesis could be on the right track. It may well be

15 Since it is much easier to find evidence that a certain marker is polysemous (finding a single other temporal use of it suffices) than it is used for time distance alone, the proportion of monosemous markers may be somewhat underestimated. However, this is unlikely to have any sizeable impact on the roughly similar proportion of dedicated past and future distancers or on their geographical distribution, which appears too consistent to have arisen by chance. 


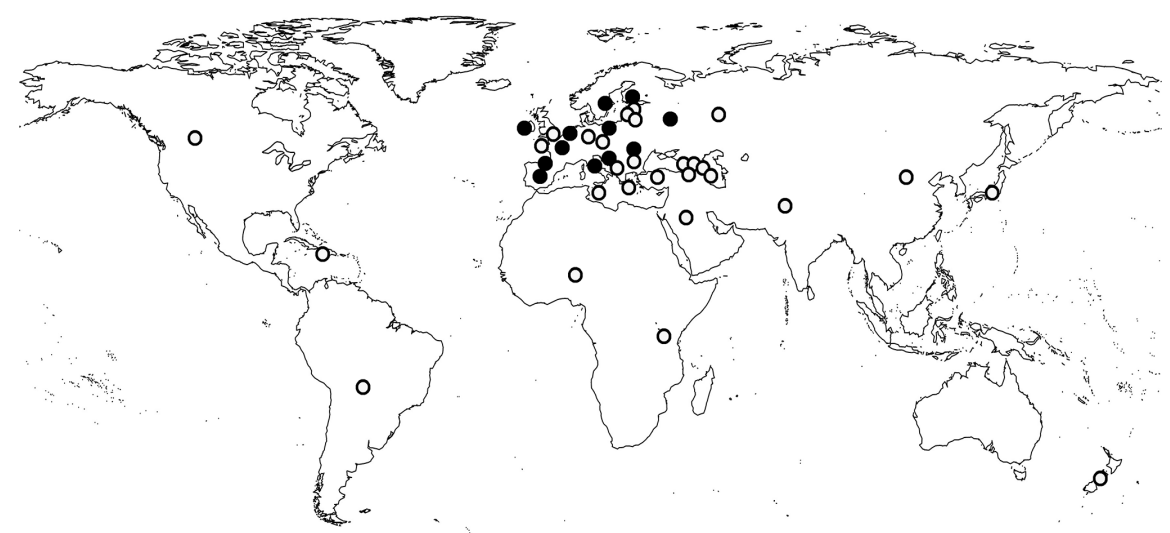

Map 3: Geographic distribution of monosemous (black circles) and polysemous (white circles) future distancers.

that there existed in Europe a greater need for an unambiguous coding of time relations because of the greater importance of time measurement in society, reflected probably in its more conspicuous presence in natural speech. As argued in Section 7, this would have favoured more specific, monosemous ways of expressing the various time relations or would have promoted the grammaticalization and loss of clausality of less grammaticalized biclausal time constructions (see e.g., Franco (2012) or Herce (forthcoming)).

\section{Conclusion and discussion}

In this article, the word order properties of time distancers were analysed and the asymmetry between past and future distancers was confirmed to be a crosslinguistically valid generalization. Past distancers have a much more remarkable word order, since even in prepositional languages the postposing of such markers is more frequent than their preposing. Future distancers, on the other hand, pattern closely like adpositions.

When the distinction between semantically dedicated and polysemous markers is introduced, another asymmetry emerges that separates monosemous, much more ill-aligned past distancers, from polysemous markers which, like future distancers, are very similar to adpositions concerning word order. When this is considered together with the additional evidence 
from the patterns of polysemy and the lexical, mainly verbal sources of many monosemous past distancers, it suggests that the differences have a diachronic origin.

I have proposed two main diachronic sources of time distancers. First, we have evidence of a secondary grammaticalization path which leads to time distancers from anterior and posterior time markers. This development can easily be accommodated in theoretical models like, for example, Functional Discourse Grammar. Hengeveld \& Mackenzie (2008: 171) note that absolute location in time is a property of episodes, while relative location in time is a property of hierarchically lower states-of-affairs. An upwards development (from the latter to the former) is the expected direction for diachronic change.

The other paths I propose here lead to time distancers from other sources. The distance-past meaning for which past distancers are used is a frequent locus of primary grammaticalization out of clausal strategies. This is evidenced by the verbal origin of many expressions (e.g., those of French, Italian, Spanish, English, Dutch, Basque, or Maltese) and by the fact that most languages can also express the distance-past time relation by means of biclausal structures. Sometimes, for example, in French or Spanish (see examples (9) to (11)), the past distancer itself can still be used as the main verb in these constructions, pointing more clearly to the diachronic connection between the two. The same is not the case for distance-future, where usually only secondary grammaticalization takes place as grammatical strategies are borrowed from the spatial domain.

Some generalizations can probably be made about these grammaticalization paths which feed directly into distance-future and distance-past. Both appear most frequently to involve a durative expression as a source. A spatial expression like 'within', which selects an interval at any point of which the event may take place, may become a dentro de type of expression through interpretative enrichment. ${ }^{16}$ All it takes is that when hearing a sentence like He will sure finish his degree within three years the hearer assumes that the speaker has been maximally informative and that the event will in fact take place towards the

16 More research would be needed at this point, however, to clarify a few things. On the one hand, a synchronic crosslinguistic study would be needed to investigate to what extent Haspelmath's observation that inessive-based markers are synchronically deictic is a valid universal tendency. On the other hand, a diachronic in-depth quantitative analysis of the semantics of expressions like dentro de could help to illuminate the grammaticalization paths followed by these expressions when they give rise to future distancers. 
end of the three years' interval. Similarly, the verbs used in biclausal constructions to express distance-past, which are frequent sources of dedicated past distancers, probably began selecting their time NP interval as a period during which the event was (or was not) taking place and not as the time interval separating the past event from the present. This contention is based on the observation that this is the only possibility found in less grammaticalized time constructions $(22 \mathrm{a}, \mathrm{b})$ and that it is a meaning which is still found occasionally in more grammaticalized past distancers (22c).

(22) Spanish

a. Llevo dos años viniendo a esta playa take.1SG two years coming to this beach 'I have been coming to this beach for two years.'

b. *Llevo dos años que vine a esta playa take.1SG two years that came.1SG to this beach [Intended meaning:] 'It has been two years since I came to this beach.'

c. Trabajo en esta escuela hace treinta años ${ }^{17}$ work.1SG in this school ago thirty years 'I have been working in this school for thirty years.'

Other past distancers which nowadays can be used exclusively for distance-past were earlier used with up-to-now durative temporal meanings as well:

(23) a. Old French

Trois jours a, ne dormi

three days ago NEG sleep.3SG

'She hasn’t slept for three days.' (Díez Itza \& Pérez Toral 1991: 49)

b. Middle English

I woot it by myself full yore agon

I know it by myself many years ago

'I have known that myself for a long time.' (Chaucer, Canterbury Tales: The Knight's Tale: 1813)

c. Early Modern Danish

Han er hos Vorherre for snese Aar siden he is with our.Lord ago tens year ago

'He has been dead for decades.' (Rasmussen 1981: 90)

17 Most Spanish speakers would nowadays prefer desde hace treinta años to describe such a temporal interval. The construction without desde, however, despite having become less widespread in the last hundred to two hundred years, continues to occur in the present language. 
In (23), the time NPs accompanying the past distancers measure intervals during which various states of affairs hold (i.e., the interval is "filled" with the states of affairs located in time). In present-day French, English, and Danish, however, these adjunct constructions can only denote a distance separating an event from the present (i.e., the time NP measures an interval which is "empty" concerning the event which is being located in time).

I believe, in addition, that the durative sources of distance-past and distance-future strategies are not limited to clausal or inessive sources respectively. These might just be the most frequent implementations of a more general tendency to link duration and distance and to diachronically derive the latter from the former. This can be observed, for example, also in future distancers like Azerbaijani arzindo, which apart from their future role (24b) can also have durative semantics (24a):

\section{a. $O$ cavab verdi bütün suallara arzinda dars}

(S)he answer PST.3SG all questions during lesson

'He/she answered all the questions during the lesson.'

b. $O$ Soz verdi onunla danışmaga bir hafta arzinda

(S)he promise PST.3SG with.her/him talk one week in

'He/she promised to talk to her/him in a week.'

This link can be found in lexical items as well. Russian davno, for instance, also combines durative, up-to-now uses (25a) and distance-past ones (25b):

a. Zapad pereživaet ètot krizis uže davno the.West goes.through this crisis already long.time 'The West has already been going through this crisis for a long time.' (2003; Russian National Corpus, http://www.ruscorpora.ru/en/searchmain.html, accessed May 2015)

b. potomu-čto ne tak davno umerla because not so long.ago died.F 'because she did not die so long ago' (2004; Russian National Corpus, accessed May 2015)

To conclude, Figure 4 graphically represents the diachronic developments that have been proposed in this section; primary grammaticalizations are shown in light grey, secondary grammaticalizations or semantic extensions in dark grey.

The asymmetries found in time distancers, therefore, have a diachronic origin. This in turn demands some explanation. The different sources of past 


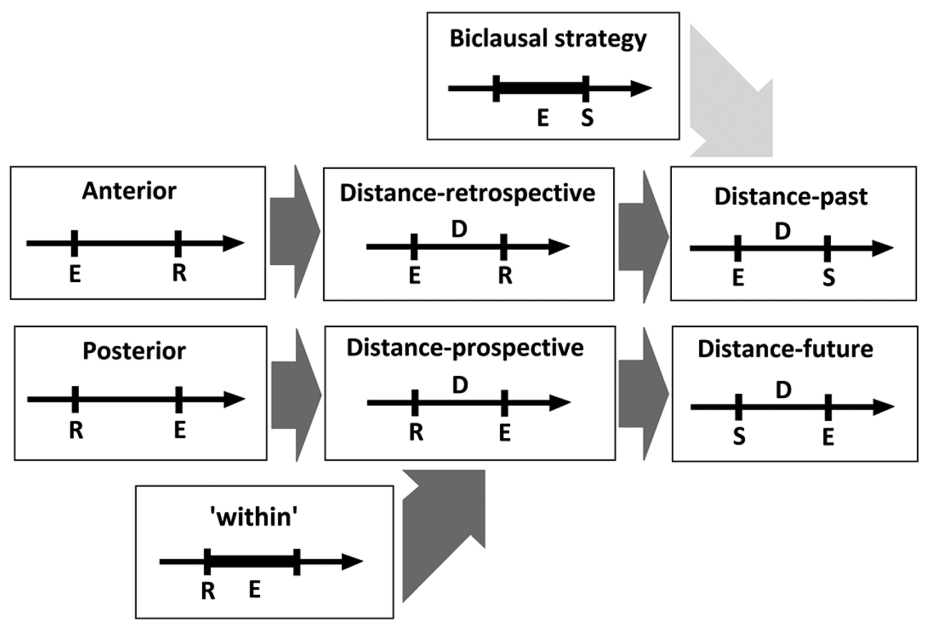

Figure 4: Diachronic sources of past and future distancers.

and future distancers might ultimately be attributable to cognitive factors. I agree here with Haspelmath (1997: 24) and Comrie (1985: 43-44), who comment that there exists a huge experiential and conceptual difference between the past and the future. In Comrie's words:

there is a sense in which the future is clearly different from the past. The past [...] is immutable, beyond the control of our present actions. The future, however, is necessarily more speculative, in that any prediction we make about the future might be changed by intervening actions, including our own conscious intervention. Thus, in a very real sense the past is more definite than the future.

As a result, the strategies that emerge to talk about the more abstract future may also make use, as we have seen, of more abstract, more grammaticalized resources and rely more heavily on space-based metaphors whereas the past may more often be expressed by lexical or discursive means.

In the languages in the sample we found that distance-future, unlike distance-past, was sometimes expressed by a grammatical case ending applied to the time NP or by a bare NP and that it was never expressed by circumpositions. In addition, much more frequently than past distance phrases, future distance phrases made use of "ordinary" adpositions (i.e., used in other domains, categorially more prototypical, more grammaticalized). Compare, e.g., English in to ago, French dans to il y $a$ and consider similarly the time distancers of Italian, Spanish, Russian, Basque, Maori, Swedish, Polish, etc. Even the mean length of 
the expressions appears to point in the same direction: in the sample languages, it is 5.35 characters on average for past distancers, but only 3.95 for future distancers. These differences and also the word order correlations of past and future distancers represent evidence that future distancers are on average much more grammaticalized and that the expression of distance-future is more abstract than that of distance-past.

Concerning space-based metaphors, it is relatively frequent for languages to rely on non-spatial resources like full clauses and verbs (also in presentatives, see Haspelmath 1997: 136-138) as sources of their past distancers (e.g., Spanish hace 'it makes', Basque duela 'that has', etc.), which is not common in the case of future distancers. Space-based metaphors are more common, therefore, in the future since, apart from space-based posteriority (parallel to also space-based anteriority for past distancers, see Figure 4), the other main source of future distancers, unlike in the past, is also space-based: the spatial inessive. Thus, along with the Spanish future distancer dentro de (inessive-spatial-based) we have the past distancer hace (non-spatial) and we find the same in Italian, French, Romanian, Polish, Basque, Finnish, etc.

Future distancers and their phrases have been shown to differ crosslinguistically from their mirror images for the past in being more grammaticalized and more reliant on space-based metaphors. Further investigation would be needed to determine whether this greater grammaticalization of the future vis-à-vis the past also applies to other time-related morphs (e.g., to verbal morphology for tense), to understand the semantic and syntactic changes proposed in Figure 4 and to document them for specific languages. Looking for measurable evidence for my claims in Section 7 concerning the different importance of time measurement in different societies would also be a desirable goal for future research for those interested in functional explanations in language.

Acknowledgements: The financial support of the European Commission's Backis Programme (2012-2741 /001-001 - EMA2) and of the Government of the Basque Country (PRE_2015_1_0175) are gratefully acknowledged. Special thanks are due to Carlos-García Castillero and Iván Igartua for their comments on earlier versions of this article. I also thank three anonymous reviewers of $L T$ for their helpful remarks.

Abbreviations: $1 / 2 / 3=1 \mathrm{st} / 2 \mathrm{nd} / 3 \mathrm{rd}$ person; $\mathrm{ABL}=$ ablative; $\mathrm{ACC}=$ accusative; $\mathrm{AUX}=$ auxiliary verb; $\mathrm{CL}=$ classifier; $\mathrm{COMP}=$ complementizer; $\mathrm{ERG}=$ ergative; $\mathrm{F}=$ feminine; $\mathrm{FD}=$ future distancer; $\mathrm{FUT}=$ future; $\mathrm{IPF}=$ imperfect; $\mathrm{IPFV}=$ imperfective; INESS = inessive; $\mathrm{LOC}=$ locative; $\mathrm{M}=$ masculine; $\mathrm{NEG}=$ negation; $\mathrm{NOM}=$ nominative; $\mathrm{PART}$ $=$ partitive; $\mathrm{PD}=$ past distancer; $\mathrm{PL}=$ plural; $\mathrm{PST}=$ past tense $; \mathrm{Q}=$ question particle; $\mathrm{REFL}=$ reflexive; $\mathrm{SG}=$ singular. 


\section{Appendix A: Word order of time distancers, their polysemy vs. monosemy, and preferred word order of adpositions for the sample languages}

\begin{tabular}{|c|c|c|c|c|c|}
\hline Language & $\begin{array}{l}\text { Past } \\
\text { distancer }\end{array}$ & $\begin{array}{l}\text { PD } \\
\text { dedicated? }\end{array}$ & $\begin{array}{l}\text { Future } \\
\text { distancer }\end{array}$ & $\begin{array}{l}\text { FD } \\
\text { dedicated? }\end{array}$ & Adposition \\
\hline Dutch & NP PD & Yes & FD NP & Yes & Prep \\
\hline English & NP PD & Yes & FD NP & No & Prep \\
\hline German & PD NP & No & FD NP & No & Prep \\
\hline Swedish & PD NP PD & Yes & FD NP & Yes & Prep \\
\hline French & PD NP & Yes & FD NP & Yes & Prep \\
\hline Italian & NP PD & Yes & FD NP & Yes & Prep \\
\hline Romanian & PD NP & Yes & FD NP & Yes & Prep \\
\hline Spanish & PD NP & Yes & FD NP & Yes & Prep \\
\hline Bulgarian & PD NP & No & FD NP & No & Prep \\
\hline Polish & NP PD & No & FD NP & Yes & Prep \\
\hline Russian & NP PD & Yes & FD NP & Yes & Prep \\
\hline Serbian/Croatian & PD NP & No & FD NP & Yes & Prep \\
\hline Hindi & NP PD & & NP FD & & Post \\
\hline Pashto & NP PD & No & & & Post \\
\hline Persian & NP PD & No & NP FD & & Prep \\
\hline Punjabi & NP PD & No & NP FD & No & Post \\
\hline Breton & NP PD & & FD NP & No & Prep \\
\hline Irish & NP PD & Yes & FD NP & Yes & Prep \\
\hline Welsh & NP PD & Yes & FD NP & & Prep \\
\hline Latvian & PD NP & No & FD NP & No & Prep \\
\hline Lithuanian & PD NP & No & FD NP & No & Prep \\
\hline Albanian & PD NP & No & FD NP & No & Prep \\
\hline Armenian & NP PD & No & NP FD & & Post \\
\hline Greek & PD NP & No & FD NP & No & Prep \\
\hline Arabic & PD NP & No & FD NP & No & Prep \\
\hline Hausa & PD NP PD & Yes & FD NP & No & Prep \\
\hline Hebrew & PD NP & No & FD NP & & Prep \\
\hline Maltese & NP PD & Yes & FD NP & No & Prep \\
\hline Mehri & PD NP & No & & & Prep \\
\hline Oromo & NP PD & No & NP PD & & Post \\
\hline Igbo & NP PD & & FD NP & & Prep \\
\hline Swahili & & & FD NP & No & Prep \\
\hline Thimbukushu & PD NP & No & & & Prep \\
\hline Yoruba & NP PD & & & & Prep \\
\hline
\end{tabular}


(continued)

\begin{tabular}{|c|c|c|c|c|c|}
\hline Language & $\begin{array}{l}\text { Past } \\
\text { distancer }\end{array}$ & $\begin{array}{l}\text { PD } \\
\text { dedicated? }\end{array}$ & $\begin{array}{l}\text { Future } \\
\text { distancer }\end{array}$ & $\begin{array}{l}\text { FD } \\
\text { dedicated? }\end{array}$ & Adposition \\
\hline Indonesian & NP PD & & NP FD & & Prep \\
\hline Maori & NP PD & Yes & FD NP & No & Prep \\
\hline Tagalog & PD NP & & FD NP & & Prep \\
\hline $\begin{array}{l}\text { Mandarin } \\
\text { Chinese }\end{array}$ & NP PD & No & NP FD & No & Post/SVO \\
\hline Taiwanese & NP PD & & NP FD & & Post/SVO \\
\hline Tibetan & NP PD & & & & Post \\
\hline Kannada & NP PD & & NP-FD & & Post \\
\hline Malayalam & NP PD & No & NP FD & & Post \\
\hline Tamil & NP PD & No & NP FD & & Post \\
\hline Telugu & NP PD & & & & \\
\hline Estonian & NP PD & Yes & NP FD & No & Post \\
\hline Finnish & NP PD & No & NP-FD & Yes & Post \\
\hline Hungarian & NP PD & No & NP FD & No & Post \\
\hline Udmurt & NP PD & No & NP FD & No & Post \\
\hline Chechen & NP PD & No & NP FD & No & Post \\
\hline Hunzib & NP PD & No & NP FD & No & Post \\
\hline Lezgian & NP PD & No & NP-FD & No & Post \\
\hline Evenki & NP PD & & & & Post \\
\hline Nanai & NP PD & & NP FD & & Post \\
\hline Udihe & NP PD & & NP FD & & Post \\
\hline Haitian & PD NP & No & FD NP & No & Prep \\
\hline Saramaccan & NP PD & & FD NP & & Prep \\
\hline Slave & NP PD & No & NP FD & No & Post \\
\hline Lao & NP PD & & FD NP & & Prep \\
\hline Thai & NP PD & & FD NP & & Prep \\
\hline Azeri & NP PD & No & NP FD & No & Post \\
\hline Turkish & NP PD & No & NP FD & No & Post \\
\hline Hopi & & & NP FD & & Post \\
\hline Abkhaz & NP PD & No & NP FD & & Post \\
\hline Abui & PD NP & Yes & & & nd/SOV \\
\hline Basque & PD NP & Yes & NP FD & Yes & Post \\
\hline Georgian & NP PD & No & NP-FD & No & Post \\
\hline Japanese & NP PD & No & NP FD & No & Post \\
\hline Kalaallisut & NP PD & No & & & Post \\
\hline Korean & NP PD & No & NP FD & & Post \\
\hline Mongolian & NP PD & & & & Post \\
\hline
\end{tabular}


(continued)

\begin{tabular}{llllll}
\hline Language & $\begin{array}{l}\text { Past } \\
\text { distancer }\end{array}$ & $\begin{array}{l}\text { PD } \\
\text { dedicated? }\end{array}$ & $\begin{array}{l}\text { Future } \\
\text { distancer }\end{array}$ & $\begin{array}{l}\text { FD } \\
\text { dedicated? }\end{array}$ & Adposition \\
\hline Quechua & Clausal & & NP-FD & No & Post \\
Semelai & NP PD & & NP & & Prep \\
Tepehua & NP PD & & NP & & Prep \\
\hline
\end{tabular}

\section{Appendix B: Examples of past and future distance phrases}

\begin{tabular}{|c|c|}
\hline $\begin{array}{l}\text { Language (source) } \\
\text { Past distance phrase }\end{array}$ & Future distance phrase \\
\hline Dutch (Donaldson 2008) & \\
\hline $\begin{array}{l}\text { twee uur geleden 'two hours ago' } \\
\text { English (personal knowledge) }\end{array}$ & over twee uur 'in two hours' \\
\hline $\begin{array}{l}\text { three hours ago } \\
\text { German (personal knowledge) }\end{array}$ & in one year \\
\hline $\begin{array}{l}\text { vor zwei Jahren 'two years ago' } \\
\text { Swedish (Haspelmath 1997: 163, 165) }\end{array}$ & in zwei Monaten 'in two months' \\
\hline $\begin{array}{l}\text { för fjorton år sedan 'fourteen years ago' } \\
\text { French (personal knowledge) }\end{array}$ & om två dagar 'in two days' \\
\hline $\begin{array}{l}\text { il y a deux ans 'two years ago' } \\
\text { Italian (personal knowledge) }\end{array}$ & dans deux jours 'in two days' \\
\hline $\begin{array}{l}\text { due anni fa 'two years ago' } \\
\text { Romanian (Mallinson 1986: 238) }\end{array}$ & tra due anni 'in two years' \\
\hline $\begin{array}{l}\text { acum o lună 'a month ago' } \\
\text { Spanish (personal knowledge) }\end{array}$ & peste o lună 'in a month' \\
\hline $\begin{array}{l}\text { hace un año 'one year ago' } \\
\text { Bulgarian (Haspelmath 1997: 164) }\end{array}$ & dentro de un año 'in one year' \\
\hline $\begin{array}{l}\text { predi edna sedmica '1 week ago' } \\
\text { Polish (Haspelmath 1997: 164) }\end{array}$ & sled edna sedmica 'in one week' \\
\hline $\begin{array}{l}\text { sześć miesięcy temu 'six months ago' } \\
\text { Russian (personal knowledge) }\end{array}$ & za tydzień 'in a week' \\
\hline $\begin{array}{l}\text { dva goda nazad 'two years ago' } \\
\text { Serbian/Croatian (Haspelmath 1997: 164, 165) }\end{array}$ & čerez god 'in a year' \\
\hline $\begin{array}{l}\text { prije četrnaest godina 'fourteen years ago' } \\
\text { Hindi (Bipasha Patgiri, personal communication) }\end{array}$ & do dva dana 'in two days' \\
\hline ek sāl pehle 'one year ago' & ek sāl bād 'in one year' \\
\hline
\end{tabular}


(continued)

\section{Language (source)}

Past distance phrase

Future distance phrase

Pashto (David 2014)

tso wradze wrānde 'some days ago'

Persian (Mahootian 2002: 187)

do sa'æt piš 'two hours ago'

Punjabi (Bhatia 1993: 211-214)

do saal páílãã 'two years ago'

Breton (Press 1986: 76)

bloaz 'zo 'a year ago'

Irish (Haspelmath 1997: 164, 165)

bliain ó shin 'a year ago'

Welsh (King 2005: 253-254)

ddwy flynedd yn ôl 'two years ago'

Latvian (Haspelmath 1997: 164, 165)

pirms gada 'a year ago'

Lithuanian (Haspelmath 1997: 164, 165)

prieš tris dienas 'three days ago'

Albanian (Buchholz \& Fiedler 1987: 384)

para disa ditësh 'a few days ago'

Armenian (Haspelmath 1997: 164, 166)

erku žam araj 'two hours ago'

Greek (Joseph \& Philippaki-Warburton 1987: 148)

prín apó jjó óres 'two hours ago'

Arabic (Haspelmath 1997: 164, 166)

munðu ParbaSati Payyaamin 'four days ago'

Hausa (Haspelmath 1997: 164, 166)

cikin awàa biyun dà sukà wucèe 'two hours ago'

Hebrew (Haspelmath 1997: 164, 166)

lifney šloša yamim 'three days ago'

Maltese (Borg \& Azzopardi-Alexander 1997: 171)

erbat ijiem ilu 'four days ago'

Mehri (Rubin 2010)

yek sa'æt dige 'in one hour'

do kànțe vicc 'in two hours'

araok miz 'in a month'

i gcionn trí lá 'in three days'

ymhen mis 'in a month'

pēc divām stundām 'in two hours'

po kelių minučiu 'in a few

minutes'

pas një jave 'in a week'

erku taru-c' heto 'in two years'

se trís óres 'in three hours'

ba९da yawmayni 'in two days'

baayan shèekaràa ukkù 'in three years'

Sod yomayim 'in two days'

fi ftit minuti 'in a few minutes'

fanōhan hōba snayn 'seven years ago'

Oromo (Owens 1985: 228)

torbáan afur dúrá 'four weeks ago'

saa'áa takko xeesatti 'in one hour'

Igbo (Ọkọnkwọ 1974)

(continued) 
(continued)

Language (source)

Past distance phrase

afo abuo gara aga 'two years ago'

Swahili (Mohammed 2001)

Thimbukushu (Fisch 1998)

kughutho ghomyaka dhiwadi 'two years ago'

Yoruba (Bamgboșe 2010)

ogún ọdún se.hìn 'twenty years ago'

Indonesian (Sneddon et al. 2012: 226)

dua minggu lalu 'two weeks ago'

Maori (Bauer 2003)

rua haora noa atu raa 'two hours ago'

Tagalog (Schachter \& Otanes 1972: 441-442)

noong isang linggo 'seven years ago'

Mandarin Chinese (Yip \& Rimmington 2009)

sì nián qián 'four years ago'

Taiwanese (Lin 2015: 510)

sì nî chêng 'four years ago'

Tibetan (Goldstein et al. 1991: 90)

lō sūmgi nōntu 'year three ago'

Kannada (Sridhar 1990: 193-194)

ardha gaNTeya hinde 'half an hour ago'

Malayalam (Asher \& Kumari 1997: 243-244)

ranta manikkuur munpa 'two hours ago'

Tamil (Asher 1982: 131-132)

muunu mani-kki munnaale 'three hours ago'

Telugu (Krishnamurti \& Gwynn 1985: 102)

gaNTa kindaTa 'an hour ago'

Estonian (Haspelmath 1997: 164, 165)

kaks tundi tagasi 'two hours ago'

Finnish (Haspelmath 1997: 164, 165)

kolme vuotta sitten 'four years ago'

Hungarian (Haspelmath 1997: 164, 165)

három hét elött 'three weeks ago'

Udmurt (Haspelmath 1997: 164, 165)

odig ar taleś aźlo 'one year ago'

Chechen (Haspelmath 1997: 164, 165)

pxi šo halxa 'five years ago'

Hunzib (van den Berg 1995: 64-65)

q'anu anx'i art'o 'two weeks ago'

\section{Future distance phrase}

n'ime afo abuo 'in two years'

baada ya siku mbili 'in two days'

dua hari lagi 'in two days'

a te rua haora 'in two hours'

sa loob ng isang linggo 'in one week'

sì nián yǐhòu 'in four years'

sì nî í-āu 'in four years'

eraDu gaNTey-alli 'in two hours'

ranta manikkuut-il 'in two hours'

rantu mani neerattle 'in two hours'

kahe tunni pärast 'in two hours'

tunnin-päästä 'in an hour’

három hét múlva 'in three weeks'

odig ćas bere 'in one hour'

ill minot jälča 'in ten minutes'

$\lambda a Y e l$ muğáx ‘in a year’ 
(continued)

Language (source)

Past distance phrase

Lezgian (Haspelmath 1993)

250 jis idalaj wilik '250 years ago'

Evenki (Nedjalkov 1997)

ilanma tyrganilva amaski 'three days ago'

Nanai (Haspelmath 1997: 164)

亏̌uer ajnaniwa xamasi 'two years ago'

Udihe (Nikolaeva \& Tolskaya 2001)

zu: nenini bimi 'two days ago'

Haitian (Haspelmath 1997: 164, 165)

fè kat jou 'four days ago'

Saramaccan (McWhorter \& Good 2012: 194)

tú dáka pasá 'two days ago'

Slave (Rice 1989: 295-297)

to dzene t'oh 'many days ago'

Lao (Khanitta Mancktelow, personal communication)

săwng ąa-thit lâew 'two weeks ago'

iik sawng deuan 'in two months'

Thai (Smyth 2014)

săam wan maa leqw 'three days ago'

Azeri (Gunel Yashar, personal communication)

üç il avval 'three years ago'

Turkish (Haspelmath 1997: 164, 165)

iki yıl önce 'two years ago'

Hopi (Malotki 1983: 36)

Abkhaz (Hewitt 1979)

$y^{\circ}$ a-sàat-k' r-àpx'a 'two hours ago'

Abui (Kratochvíl 2007)

afe hetung nuku 'a year ago'

Basque (personal knowledge)

duela ehun urte 'one hundred years ago'

Georgian (Haspelmath 1997: 164, 165)

or saatis c'in 'two hours ago'

Japanese (Hinds 2003: 221)

nijikan mae kara 'two hours ago'

Kalaallisut (Fortescue1984: 241)

nalunaaquttap akunniri pingasut matuma siurnagut 'three hours ago'
Future distance phrase

q'we wacra-laj 'in two months'

umun bega-li 'in one month'

క̌uer ajpani-du bipie 'in two years'

tunama neni bis'esi 'in five days'

nan kèk jou ankò 'in a few days'

báka dii sába 'in three Saturdays'

tai dzene ndah 'in three days'

iik săwng dęuan 'in two months'

iik hòk wan 'in six days'

üç il arzinda 'in three years'

iki gün sonra 'in two days'

hikis taala-t ang 'in a few days'

$y^{\circ}$ a-sàat-k' rà-la 'in two hours'

bi urte barru 'in two years'

or saat-ši 'in two hours'

nijikan de 'in two hours' 
(continued)

\section{Language (source)}

Past distance phrase

Korean (Haspelmath 1997: 164, 166)

twu sikan cen-ey 'two hours ago'

Mongolian (Gaunt \& Bayarmandakh 2004)

gurvan ødriin ømnø 'three days ago'

Quechua (Cole 1985: 126-127)

Semelai (Kruspe 2004)

hmpe? Pare? loc 'three days ago'

Tepehua (Kung 2007: 505)

miix-kiis-chich 'five days ago'

\section{Future distance phrase}

sam nyen twi-ey 'in three years'

ishkay uras-pi 'in two hours'

hmpe? ?are? 'in three days'

miix-kiis 'in five days'

For the languages lacking the relevant structures see Givón (2011) for Ute, Carlson (1994) for Supyire, Valentine (2001) for Nishnaabemwin, Dayley (1985) for Tzutujil, Macaulay (1996) for Mixtec, Besnier (2002: 354-355) for Tuvaluan, Maslova (2003) for Yukaghir, Cook (2013) for Tsilhqút’ín, van den Berg (1989) for Muna, Noonan (1992) for Lango, Guillaume (2008) for Caviñena, Meakins \& Nordlinger (2013) for Bilinarra, Plaisier (2006) for Lepcha, Simpson (1983) for Warlpiri, Derbyshire (1985) for Hixkaryana, Bowern (2012) for Bardi, Aikhenvald (2003) for Tariana, Nedjalkov \& Otaina (2013) for Nivkh, Wegener (2012) for Savosavo, Dixon \& Vogel (2004) for Jarawara, Evans (1995) for Kayardild, Terrill (2003) for Lavukaleve, and Childs (2011) for Mani.

\section{References}

Aikhenvald, Alexandra Y. 2003. A grammar of Tariana, from northwest Amazonia. Cambridge: Cambridge University Press.

Asher, R. E. 1982. Tamil. Amsterdam: North-Holland.

Asher, R. E. \& T. C. Kumari. 1997. Malayalam. London: Routledge.

Bamgboșe, Ayọ. 2010. A grammar of Yoruba. Cambridge: Cambridge University Press.

Bauer, Winifred. 2003. Maori. London: Routledge.

Besnier, Niko. 2002. Tuvaluan: A Polynesian language of the central Pacific. London: Routledge. Bhatia, Tej. 1993. Punjabi. London: Routledge.

Borg, Albert J. \& Marie Azzopardi-Alexander. 1997. Maltese. London: Routledge.

Bourdin, Philippe. 2011. Ten years ago and ten years since: Competition and standardization in Early Modern English. Groninger Arbeiten zur Germanistischen Linguistik 53. 45-70.

Bowern, Claire. 2012. A grammar of Bardi. Berlin: De Gruyter Mouton. 
Brown, James Dean. 2004. Yates correction factor. Shiken: JALT Testing \& Evaluation SIG

Newsletter 8(1). 22-27.

Buchholz, Oda \& Wilfried Fiedler. 1987. Albanische Grammatik. Leipzig: Enzyklopädie.

Bybee, Joan. 2010. Language, usage and cognition. Cambridge: Cambridge University Press.

Carlson, Robert. 1994. A grammar of Supyire. Berlin: Mouton de Gruyter.

Childs, G. Tucker. 2011. A grammar of Mani. Berlin: De Gruyter Mouton.

Cole, Peter. 1982. Imbabura Quechua. Amsterdam: North-Holland.

Comrie, Bernard. 1985. Tense. Cambridge: Cambridge University Press.

Cook, Eung-Do. 2013. A Tsilhqút'ín grammar. Vancouver: UBC Press.

Culicover, Peter W. 1999. Syntactic nuts: Hard cases, syntactic theory, and language acquisition. Oxford: Oxford University Press.

David, Anne. 2014. Descriptive grammar of Pashto and its dialects. Berlin: De Gruyter Mouton.

Dayley, Jon P. 1985. Tzutujil grammar. Berkeley, CA: University of California Press.

Derbyshire, Desmond C. 1985. Hixkaryana and linguistic typology. Dallas: Summer Institute of Linguistics.

Deutscher, Guy. 2000. Syntactic change in Akkadian: The evolution of sentential complementation. Oxford: Oxford University Press.

Díez Itza, Eliseo \& Marta Pérez Toral. 1991. Las formas verbales de ciertas expresiones temporales en las lenguas románicas: Un estudio de morfosintaxis histórica comparada. Oviedo: Universidad de Oviedo.

Dixon, R. M. W. 1972. The Dyirbal language of north Queensland. Cambridge: Cambridge University Press.

Dixon, R. M. W. 2010. Basic Linguistic Theory, Vol. 1: Methodology. Oxford: Oxford University Press.

Dixon, R. M. W. \& Alan Vogel. 2004. The Jarawara language of southern Amazonia. Oxford: Oxford University Press.

Donaldson, Bruce C. 2008. Dutch: A comprehensive grammar. London: Routledge.

Evans, Nicholas D. 1995. A grammar of Kayardild, with historical-comparative notes on Tangkic. Berlin: Mouton de Gruyter.

Everett, Daniel L. \& Barbara Kern. 1997. Wari': The Pacaas Novos language of western Brazil. London: Routledge.

Fábregas, Antonio. 2016. On the structure and variation of 'hace' as a temporal expression. Stellenbosch Papers in Linguistics 45. 77-108.

Fisch, Maria. 1998. Thimbukushu grammar. Windhoek: Out of Africa.

Fortescue, Michael. 1984. West Greenlandic. London: Croom Helm.

Franco, Ludovico. 2012. Movement triggers and the etiology of grammaticalization: The case of Italian postposition fa. Sintagma 24. 65-83. http://www.sintagma.udl.cat/export/sites/

Sintagma/documents/articles_24/franco.pdf

Franco, Ludovico. 2013. Before strikes back: An *ABA constraint on temporal expressions. Acta Linguistica Hungarica 60. 265-301.

Gaunt, John \& L. Bayarmandakh. 2004. Modern Mongolian: A course-book. London: RoutledgeCurzon.

Givón, Talmy. 2011. Ute reference grammar. Amsterdam: Benjamins.

Goldstein, Melvyn C., Gelek Rimpoche \& Lobsang Phuntshog. 1991. Essentials of modern literary Tibetan: A reading course and reference grammar. Berkeley, CA: University of California Press.

Guillaume, Antoine. 2008. A grammar of Cavineña. Berlin: Mouton de Gruyter. 
Haspelmath, Martin. 1993. A grammar of Lezgian. Berlin: Mouton de Gruyter.

Haspelmath, Martin. 1997. From space to time: Temporal adverbials in the world's languages. München: Lincom Europa.

Hengeveld, Kees \& J. Lachlan Mackenzie. 2008. Functional Discourse Grammar: A typologicallybased theory of language structure. Oxford: Oxford University Press.

Herce, Borja. Forthcoming. The diachrony of Spanish haber/hacer + time: A quantitative corpusbased approach to grammaticalization. Journal of Historical Linguistics.

Hewitt, Brian G. 1979. Abkhaz. Amsterdam: North-Holland.

Hinds, John. 2003. Japanese: Descriptive grammar. London: Routledge.

Joseph, Brian D. \& Irene Philippaki-Warburton. 1987. Modern Greek. London: Croom Helm.

Karlsson, Fred. 1991. Gramática básica del finés. Translated by Ursula Ojanen. Madrid:

Universidad Autónoma de Madrid.

Karlsson, Fred. 2008. Finnish: An essential grammar. London: Routledge.

King, Gareth. 2005. Modern Welsh: A comprehensive grammar. London: Routledge.

Kornfilt, Jaklin. 1997. Turkish. London: Routledge.

Kratochvíl, František. 2007. A grammar of Abui: A Papuan language of Alor. Leiden: Universiteit Leiden doctoral dissertation. http://www.lotpublications.nl/Documents/157_fulltext.pdf

Krishnamurti, Bhadriraju \& J. P. L. Gwynn. 1985. A grammar of modern Telugu. Delhi: Oxford University Press.

Kruspe, Nicole. 2004. A grammar of Semelai. Cambridge: Cambridge University Press.

Kung, Susan Smythe. 2007. A descriptive grammar of Huehuetla Tepehua. Austin, TX: University of Texas at Austin doctoral dissertation. http://hdl.handle.net/2152/3137

Kurzon, Dennis. 2008. "Ago" and its grammatical status in English and in other languages. In Dennis Kurzon \& Silvia Adler (eds.), Adpositions: Pragmatic, semantic and syntactic perspectives, 209-227. Amsterdam: Benjamins.

Lin, Philip T. 2015. Taiwanese grammar: A concise reference. Greenhorn Media.

Macaulay, Monica Ann. 1996. A grammar of Chalcatongo Mixtec. Berkeley, CA: University of California Press.

Mahootian, Shahrzad. 2002. Persian. London: Routledge.

Mallinson, Graham. 1986. Rumanian. London: Croom Helm.

Malotki, Ekkehart. 1983. Hopi time: A linguistic analysis of the temporal concepts in the Hopi language. Berlin: Mouton de Gruyter.

Maslova, Elena. 2003. A grammar of Kolyma Yukaghir. Berlin: Mouton de Gruyter.

McWhorter, John \& Jeff Good. 2012. A grammar of Saramaccan Creole. Berlin: De Gruyter Mouton.

Meakins, Felicity \& Rachel Nordlinger. 2013. A grammar of Bilinarra: An Australian Aboriginal language of the Northern Territory. Berlin: De Gruyter Mouton.

Mohammed, M. A. 2001. Modern Swahili grammar. Nairobi: East African Educational Pulishers.

Móia, Telmo. 2011. Expressões temporais com haver: Gramaticalização e interpretação semântica. In Armanda Costa, Isabel Falé \& Pilar Barbosa (eds.), XXVI Encontro Nacional da Associação Portuguesa de Linguística: Textos seleccionados, 401-419. Lisboa: Associação Portuguesa de Linguística. http://www.apl.org.pt/docs/26-textos-selecciona dos/Moia.pdf

Nedjalkov, Igor. 1997. Evenki. London: Routledge.

Nedjalkov, Vladimir P. \& Galina A. Otaina. 2013. A syntax of the Nivkh language: The Amur dialect. Amsterdam: Benjamins.

Nikolaeva, Irina \& Maria Tolskaya. 2001. A grammar of Udihe. Berlin: Mouton de Gruyter. 
Noonan, Michael. 1992. A grammar of Lango. Berlin: Mouton de Gruyter.

Ọkọnkwọ, Matthew Nneka. 1974. A complete course in Igbo grammar for secondary schools and teacher training colleges. Lagos: Macmillan Nigeria.

Owens, Jonathan. 1985. A grammar of Harar Oromo (northeastern Ethiopia): Including a text and a glossary. Hamburg: Buske.

Plaisier, Heleen. 2006. A grammar of Lepcha. Leiden: Brill.

Plank, Frans. 2011. Where's diachrony? Linguistic Typology 15. 455-471.

Press, Ian J. 1986. A grammar of modern Breton. Berlin: Mouton de Gruyter.

Rasmussen, Poul. 1981. El verbo hacer en expresiones temporales: Estudio sintáctico y semántico (Études romanes de l'Université de Copenhague 22). København: Akademisk Forlag.

Rice, Keren. 1989. A grammar of Slave. Berlin: Mouton de Gruyter.

Rigau, Gemma. 2001. Temporal existential constructions in Romance. In Yves D’hulst, Johan Rooryck \& Jan Schroten (eds.), Romance languages and linguistic theory 1999, 307-333. Amsterdam: Benjamins.

Rubin, Aaron D. 2010. The Mehri language of Oman. Leiden: Brill.

Schachter, Paul \& Fe T. Otanes. 1972. Tagalog reference grammar. Berkeley, CA: University of California Press.

Schapper, Antoinette. 2014. Elevation in the spatial deictic systems of Alor-Pantar languages. In Marian Klamer (ed.), The Alor-Pantar languages: History and typology, 247-284. Berlin: Language Science Press. http://langsci-press.org/catalog/book/22

Schaub, Willi. 1985. Babungo. London: Croom Helm.

Simpson, Jane Helen. 1983. Aspects of Warlpiri morphology and syntax. Cambridge, MA: Massachusetts Institute of Technology doctoral dissertation. http://hdl.handle.net/1721.1/ 15468

Smyth, David. 2014. Thai: An essential grammar. London: Routledge.

Sneddon, James Neil, K. Alexander Adelaar, Dwi N. Djenar \& Michael Ewing. 2012. Indonesian: A comprehensive grammar. London: Routledge.

Sridhar, S. N. 1990. Kannada. London: Routledge.

Sulkala, Helena \& Merja Karjalainen. 1992. Finnish. London: Routledge.

Terrill, Angela. 2003. A grammar of Lavukaleve. Berlin: Mouton de Gruyter.

Valentine, J. Randolph. 2001. Nishnaabemwin reference grammar. Toronto: University of Toronto Press.

van den Berg, Helma. 1995. A grammar of Hunzib. München: Lincom Europa.

van den Berg, René. 1989. A grammar of the Muna language. Dordrecht: Foris.

van der Auwera, Johan \& Dónall P. Ó Baoill (eds.). 1998. Adverbial constructions in the languages of Europe. Berlin: Mouton de Gruyter.

Wegener, Claudia Ursula. 2012. A grammar of Savosavo. Berlin: De Gruyter Mouton.

Yip, Po-Ching \& Don Rimmington. 2009. Basic Chinese: A grammar and workbook. 2nd edn. London: Routledge. 